\title{
TEKNIK PENANGKAPAN DAN PENGOPERASIAN PANCING RAWAI DASAR UNTUK MENANGKAP KAKAP MERAH DI LAUT ARAFURA DAN SEKITARNYA
}

\author{
Sawon, Suwardi, dan A. Salim \\ Teknisi Litkayasa pada Balai Riset Perikanan Laut, Jakarta
}

\section{PENDAHULUAN}

Dari berbagai komoditas ikan laut, ikan kakap merah mempunyai peranan penting dalam meningkatkan devisa negara serta dalam meningkatkan bahan makanan (protein hewani) untuk konsumsi lokal.

Selain kulit dan gelembung udara daging ikan kakap merah merupakan komoditas ekspor dan kulit ikan kakap dapat digunakan berbagai macam bahan seperti untuk sepatu, tas, dompet, dan jenis perhiasan lainnya. Ikan kakap merah selain harganya mahal juga merupakan andalan ekspor non migas untuk pemasukan devisa bagi negara dan dagingnya merupakan bahan makanan yang sangat lezat.

Potensi hasil dan sebaran ikan kakap di Indonesia belum banyak diketahui, padahal aspek ini sangat diperlukan untuk pengelolaannya. Di samping itu penangkapan komoditas ikan kakap selama ini dilakukan tanpa memperhatikan kaidah-kaidah kelestariannya.

Pengoperasian pancing rawai dasar dilakukan dengan mengunakan kapal KM. Laut Tri. Kapal tersebut dilengkapi dengan GPS eco sounder, line hauller, dan perlengkapan kerja lainnya.

\section{DISKRIPSI KAPAL DAN ALAT TANGKAP}

\section{Kapal}

Kapal yang dipakai untuk penangkapan ikan kakap merah ialah kapal kayu yang dibuat di galangan kapal Tanjung Balai pada tahun 1995. Kapal tersebut mempunyai ukuran panjang (LOA) $23,10 \mathrm{~m}$, lebar (W) 6,00 m, dalam (D) 2,20 m, dan GT 71, kecepatan 7,6 mil/jam dan jumlah palkah 7 buah. Mesin utama Hino 360 PK
(10 sld), mesin pembantu Nissan 100 PK, generator Mitsubishi 4 silinder, dinamo berkekuatan 40.000 watt, dan alat penarik pancing adalah line houller. Sarana navigasinya berupa GPS Furuno 31, Radio SSB ICOM-707, Kompas, Peta pelayaran, dan peralatan lainnya. Kapal ini diawaki 10 orang $A B K$ dan lama melaut antara 4-5 bulan dengan basis transit penampungan ikan di Benjina dan Kupang.

\section{Pancing}

Dimensi pancing rawai dasar jumlah 1.800 buah dengan ukuran nomor 4 , tali utama (main line) monofilament $\phi 5 \mathrm{~mm}$, panjang $4.500 \mathrm{~m}$, tali cabang (brane line) monofilament $\phi 2 \mathrm{~mm}$, panjang $1,30 \mathrm{~m}$. Tali pelampung PE $\phi 6 \mathrm{~mm}$, panjang $120 \mathrm{~m}$, jumlah pelampung 30 buah, pemberat timah 90 buah @ $0.0,5 \mathrm{~kg}$ dan jarak antar tali cabang $2,5 \mathrm{~m}$. Panjang tiap sub basket (60 mata pancing) $=150 \mathrm{~m}, 1$ buah pelampung $\phi 10$ $\mathrm{cm}$ dan 3 buah pemberat timah @. 0,5 kg. Panjang satu basket (600 mata pancing) $=1.500$ $\mathrm{m}, 1$ buah bendera + lampu, 10 buah pelampung bulat $\phi 10 \mathrm{~cm}$, dan 30 buah pemberat timah (a). $0,5 \mathrm{~kg}$. Panjang tiga basket atau 3 unit $(1.800$ mata pancing) $=4.500 \mathrm{~m}, 3$ buah bendera + lampu, 30 buah pelampung bulat $\phi 10 \mathrm{~cm}$ dan 90 buah pemberat timah $(a) .0,5 \mathrm{~kg}$. Pemberat timah (a) $0,5 \mathrm{~kg}$ dipasang pada setiap jarak 20 meter (setiap 8 buah mata pancing). Lihat (Gambar 1)

\section{PENANGKAPAN DAN PENGOPERASIAN}

\section{Penangkapan}

Penangkapan ikan kakap di laut Arafura pada umumnya masih dalam skala menengah dan belum menggunakan teknologi canggih. Daerah operasionalnya berkisar antara $04^{\circ}-08^{\circ} \mathrm{LS}$ dan 


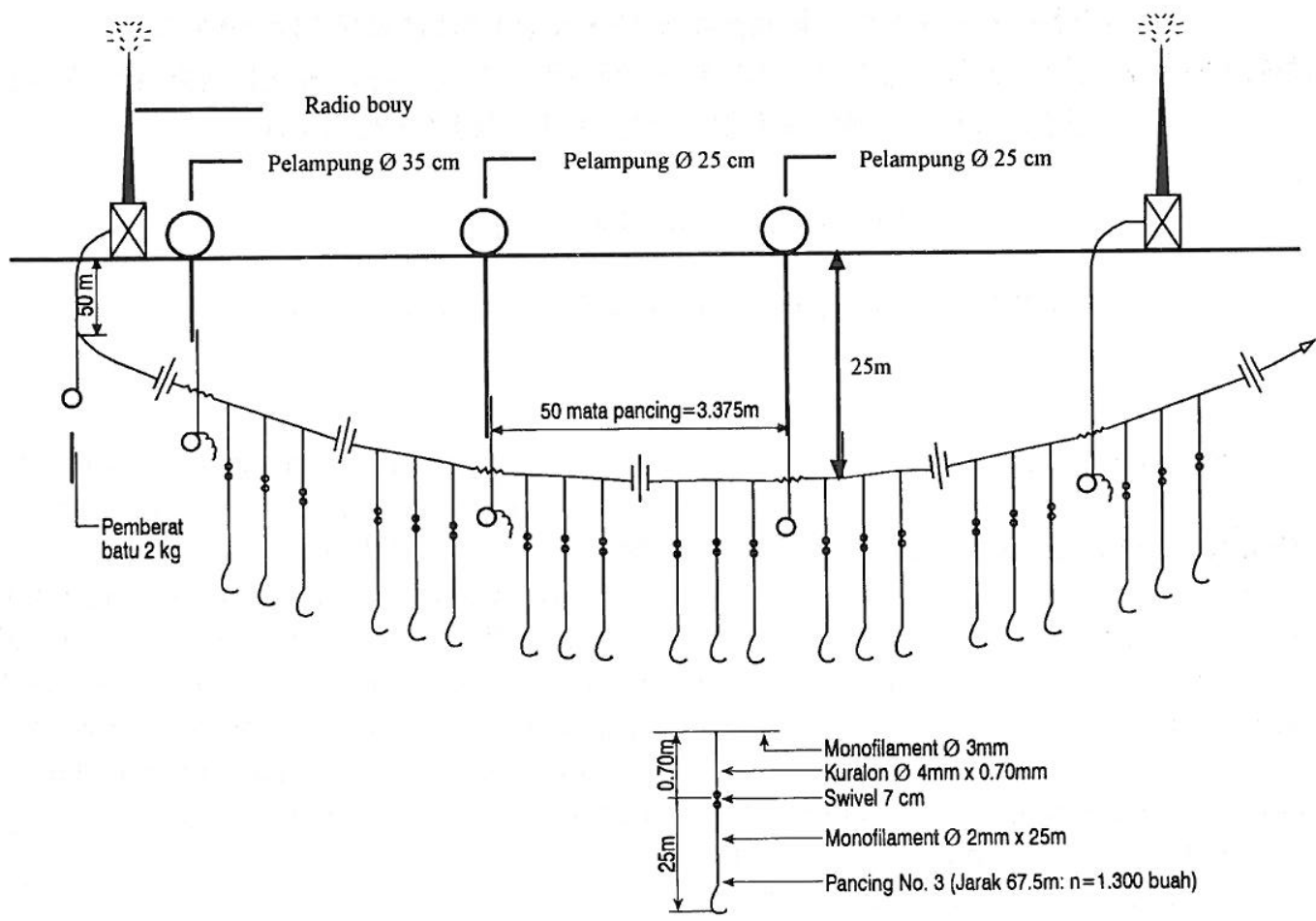

Gambar 1. Rancang bangun dan konstruksi pancing longline.

$134^{\circ}-137^{\circ}$ BT. Kapal yang digunakan terbuat dari kayu dengan berat kotor 71 GT dan daya kekuatan mesin 360 PK dengan kecepatan 7,6 mil per jam.

Pancing rawai yang dioperasikan mempunyai jumlah mata pancing 1.800 buah ( 3 unit). Umpan yang digunakan terdiri dari ikan layan£ (Decapterus russeli) dan lemuru (Sardinella longiceps) yang telah dibekukan dengan rata-rata $\mathrm{FL}=11,2 \mathrm{~cm}, \mathrm{TL}=12,7 \mathrm{~cm}$, dan berat $(\mathrm{W})=$ $51,1 \mathrm{~g}$ yang setiap ekornya dipotong menjadi tiga bagian.

Daerah penangkapan dan operasi penangkapan ikan kakap selama penelitian terdiri dari 61 lokasi dengan kedalaman antara 50-80 m. Dengan hasil tangkapan 2.850 ekor, berat $7.731,3 \mathrm{~kg}$, mereka terdiri dari 21 spesies dan didominasi oleh ikan kakap merah (Lutjanus malabaricus) sebanyak 606 ekor $(21,26 \%)$ berat $2.047,9 \mathrm{~kg}(26,49 \%)$.

Daerah penangkapan di Arafura pada posisi $05^{\circ} .17^{\prime} .08^{\prime \prime}$ - $05^{\circ} .54^{\prime} .50^{\prime \prime}$ LS dan $133^{\circ} .10^{\prime} .44^{\prime \prime}$ $135^{\circ} .57^{\prime} .57^{\prime \prime}$ BT. Lama penurunan alat 25-35 menit, lama penarikan alat 120-150 menit. Jumlah pancing 1.605-1.800 mata pancing, hasil tangkapan 22-82 ekor atau 62,6-202,0 kg.

\section{Pengoperasian Alat}

a. Pengoperasian pancing rawai dasar dilakukan dengan sistem horisontal, artinya posisi arah pancing pertama sampai yang terakhir satu arah dan setelah selesai penurunan atau setting langsung dilakukan penarikan haulling.

b. Penurunan atau setting dilakukan setiap kapal sampai pada posisi yang dituju, tidak tergantung waktu dan jam baik malam maupun siang hari.

c. Lama penurunan atau setting berkisar antara 30-45 menit, tergantung jumlah pancing yang dioperasikan dan kondisi perairan.

d. Penarikan atau haulling dimulai dari pancing yang terakhir diturunkan, lama penarikan berkisar antara 2-3 jam, tergantung jumlah pancing yang dioperasikan dan kondisi perairan.

e. Pada setiap sub basket (60 mata pancing) $=$ $150 \mathrm{~m}$, dipasang 1 buah pelampung $\phi 10 \mathrm{~cm}$ dan 3 buah pemberat timah $=(a) .0,5 \mathrm{~kg}$.

f. Pada setiap 1 basket (600 mata pancing) = $1.500 \mathrm{~m}$, dipasang 1 buah bendera + lampu, 10 buah pelampung bulat $\phi 10 \mathrm{~cm}$, dan 30 buah pemberat timah $@$, $.0,5 \mathrm{~kg}$.

g. Pada setiap 3 basket $(1.800$ mata pancing $)=$ $4.500 \mathrm{~m}$, dipasang 3 buah bendera + lampu, 30 
buah pelampung bulat $\phi 10 \mathrm{~cm}$, dan 90 buah pemberat timah (a). $0,5 \mathrm{~kg}$.

h. Pemberat timah (a). 0,5 kg dipasang pada setiap jarak $20 \mathrm{~m}$ (setiap 8 buah mata pancing).

i. Penarikan pancing rawai dilakukan dengan alat bantu (line hauller) berkisar antara 2-3 jam.

j. Pergantian/shift ABK dilakukan pada setiap 2 jam sekali.

\section{HASIL TANGKAPAN}

\section{Laju Tangkap}

Hasil tangkapan keseluruhan pancing rawai dasar dari 61 kali setting dengan jumlah rata-rata mata pancing 1.786 buah berhasil tertangkap ikan sebanyak 2.850 ekor, berat $7.731,3 \mathrm{~kg}$. Dengan demikian laju tangkap hook rate rata-rata $=46,72$ ekor $(2,61 \%)$ dengan berat $126,74 \mathrm{~kg}(7,09 \%)$.

Laju tangkap hook rate tertinggi tertangkap pada posisi $05^{\circ} .23^{\mathrm{I}} .179^{\mathrm{II}}$ LS- $135^{\circ} .66^{1} .450^{\mathrm{II}}$ BT (setting ke-10) jumlah mata pancing 1.800 buah dengan hasil tangkapan 82 ekor $(4,55 \%)$ berat $202,0 \mathrm{~kg}(11,22 \%)$.

Sedangkan laju tangkap hook rate terendah tertangkap pada posisi $05^{\circ} .15 .000^{\mathrm{II}}$ LS$134^{\circ} .30^{\mathrm{I}} .000^{\mathrm{II}}$ BT (setting ke-61) jumlah mata pancing 1.775 buah dengan hasil tangkapan 22 ekor $(1,24 \%)$ berat $65,5 \mathrm{~kg}(3,69 \%)$.

\section{Komposisi}

Hasil tangkapan keseluruhan pancing rawai dari 61 kali setting dengan jumlah rata-rata mata pancing 1.786 buah berhasil ditangkap ikan 21 jenis ikan sejumlah 2.850 ekor dan berat 7.731,3 kg.

Hasil tangkapan tertinggi ke-1 adalah kakap merah (Lutjanus malabaricus) 606 ekor $(21,26 \%)$ berat $2.047,9 \mathrm{~kg}(26,49 \%)$, tertinggi ke-2 adalah babi atau lencam (Lethrinus lentjam) 449 ekor $(15,75 \%)$ berat $1.084,7 \mathrm{~kg}(14,03 \%)$ dan tertinggi ke-3 adalah kakap sawo (Lutjanus lemniscatus) 208 ekor $(7,31 \%)$ berat $677,6 \mathrm{~kg}(8,76 \%)$.
Sedangkan hasil tangkapan terendah adalah kerapu sunu (Plectropoma leopardus) 30 ekor $(1,05 \%)$ berat $74,1 \mathrm{~kg}(0,96 \%)$ dan lain-lain 15 ekor $(0,53 \%)$ dan berat $39,1 \mathrm{~kg}(0,50 \%)$. Lihat (Tabel 1).

\section{Kisaran}

Sebaran (kisaran) panjang total (TL) dan berat (W) ikan kakap hasil tangkapan pancing rawai dasar yang digunakan dalam kegiatan observer bulan Juni 2002 di Laut Arafura dengan KM. Laut Tri adalah:

a. Kurisi bali/anggoli (Pristipomoides multidens) sebanyak 68 ekor dengan kisaran (TL) 51-80 $\mathrm{cm}$ dan berat $(\mathrm{W}) 1,1-5,0 \mathrm{~kg}$.

b. Kakap merah (Lutjanus malabaricus) sebanyak 266 ekor dengan kisaran (TL) 31-90 $\mathrm{cm}$ dan berat (W) $0,1-9,0 \mathrm{~kg}$.

c. Kakap merah (Lutjanus erythropterus) sebanyak 120 ekor dengan kisaran (TL) 31-90 $\mathrm{cm}$ dan berat (W) $0,1-8,0 \mathrm{~kg}$.

d. Babi atau lencam (Lethrinus lencam) sebanyak 120 ekor dengan kisaran (TL) 31-70 cm dan berat (W) $1,1-4,0 \mathrm{~kg}$.

e. Kakap seto (Lutjanus sebae) sebanyak 84 ekor dengan kisaran (TL) $31-90 \mathrm{~cm}$ dan berat (W) $0,1-7,0 \mathrm{~kg}$.

f. Kakap putih (Lutjanus vittus) sebanyak 58 ekor dengan kisaran (TL) 31-70 $\mathrm{cm}$ dan berat (W) $1,1-6,0 \mathrm{~kg}$.

g. Kakap merah (Lutjanus timoriensis) sebanyak 60 ekor dengan kisaran (TL) $31-70 \mathrm{~cm}$ dan berat (W) $0,1-6,0 \mathrm{~kg}$.

\section{Morfometrik}

Pengukuran dan identifikasi terhadap ikan kakap meliputi jenis atau spesies, panjang cagak (FL), panjang total (TL), tinggi ikan pada bagian terbesar (D. max), dan berat ikan (W). Dari hasil penelitian di atas kapal KM. Laut Tri di Laut Arafura berhasil diukur ikan sebanyak 776 ekor dengan berat $2.506,6 \mathrm{~kg}$, terdiri dari 7 spesies yaitu:

a. Kurisi bali atau anggoli (Pristipomoides multidens) sebanyak 68 ekor berat $253,4 \mathrm{~kg}$ dengan panjang total (TL) minimum $58,0 \mathrm{~cm}$ dan maksimum $76,0 \mathrm{~cm}$, berat $(\mathrm{W})$ minimum $2,0 \mathrm{~kg}$, dan maksimum $4,9 \mathrm{~kg}$. 
Tabel 1. Komposisi hasil tangkapan pancing rawai dasar di laut Arafura

\begin{tabular}{|c|c|c|c|c|c|}
\hline \multirow{2}{*}{ No. } & \multirow{2}{*}{ Spesies } & \multicolumn{2}{|c|}{ Hasil Tangkapan } & \multicolumn{2}{|c|}{ Rata-rata } \\
\hline & & (ekor) & (kg) & $(\%)$ & $(\%)$ \\
\hline 1 & $\begin{array}{l}\text { Kurisi bali/anggoli } \\
\text { (Pristipomoides multidens) }\end{array}$ & 146 & 495,3 & 5,12 & 6,41 \\
\hline 2 & $\begin{array}{l}\text { Kakap merah } \\
\text { (Lutjanus malabaricus) }\end{array}$ & 606 & $2.047,9$ & 21,26 & 26,49 \\
\hline 3 & $\begin{array}{l}\text { Kakap merah } \\
\text { (Lutjanus erythropterus) }\end{array}$ & 140 & 435,7 & 4,91 & 5,64 \\
\hline 4 & $\begin{array}{l}\text { Babi/lencam } \\
\text { (Lethrinus lentjam) }\end{array}$ & 449 & $1.084,7$ & 15,75 & 14,03 \\
\hline 5 & $\begin{array}{l}\text { Kakap seto } \\
\text { (Lutjanus sebae) }\end{array}$ & 121 & 384,7 & 4,25 & 4,98 \\
\hline 6 & $\begin{array}{l}\text { Kakap putih } \\
\text { (Lutjanus vittus) }\end{array}$ & 72 & 219,4 & 2,53 & 2,84 \\
\hline 7 & $\begin{array}{l}\text { Kakap merah } \\
\text { (Lutjanus timoriensis) }\end{array}$ & 95 & 308,0 & 3,33 & 3,98 \\
\hline 8 & $\begin{array}{l}\text { Kakap sawo } \\
\text { (Lutjanus lemniscatus) }\end{array}$ & 208 & 677,6 & 7,31 & 8,76 \\
\hline 9 & $\begin{array}{l}\text { Kakap merah } \\
\text { (Lutjanus sp.) }\end{array}$ & 26 & 77,1 & 0,91 & 0,99 \\
\hline 10 & $\begin{array}{l}\text { Kerapu Lumpur } \\
\text { (Epinephelus taivina) }\end{array}$ & 45 & 161,7 & 1,58 & $2,() 9$ \\
\hline 11 & $\begin{array}{l}\text { Kerapu susu } \\
\text { (Plectropoma leopardus) }\end{array}$ & 30 & 74,1 & 1,05 & 0,96 \\
\hline 12 & $\begin{array}{l}\text { Kerapu macan } \\
\text { (Epinephelus merra) }\end{array}$ & 54 & 217,5 & 1,89 & 2.81 \\
\hline 13 & $\begin{array}{l}\text { Manyung } \\
\text { (Arius thalassinus) }\end{array}$ & 75 & 262,8 & 2,63 & 3,40 \\
\hline 14 & $\begin{array}{l}\text { Utik } \\
\text { (Arius sp.) }\end{array}$ & 81 & 54,0 & 2,84 & 0,70 \\
\hline 15 & $\begin{array}{l}\text { Cucut } \\
\text { (Shrak spp.) }\end{array}$ & 38 & 167,0 & 1,33 & 2,16 \\
\hline 16 & $\begin{array}{l}\text { Pari } \\
\text { (Dasyatidae) }\end{array}$ & 116 & 444,1 & 4,07 & 5,74 \\
\hline 17 & $\begin{array}{l}\text { Remang } \\
\text { (Congresox talabon) }\end{array}$ & 62 & 179,5 & 2,18 & 2,32 \\
\hline 18 & $\begin{array}{l}\text { Gerong / kuwe } \\
\text { (Caranx sexfasciatus) }\end{array}$ & 68 & 145,2 & 2,39 & 1,88 \\
\hline 19 & $\begin{array}{l}\text { Buntek } \\
\text { (Cantigaster sp.) }\end{array}$ & 87 & 73,4 & 3,05 & 0,95 \\
\hline 20 & $\begin{array}{l}\text { Beloso } \\
\text { (Saurida sp.) }\end{array}$ & 316 & 183,0 & 11,09 & 2,37 \\
\hline 21 & $\begin{array}{l}\text { Lain-lain } \\
\text { (Others fish) }\end{array}$ & 15 & 39,1 & 0,53 & 0,50 \\
\hline & JUMLAH & 2.850 & $7.731,8$ & 100,00 & 100.00 \\
\hline
\end{tabular}


b. Kakap merah (Lutjanus malabaricus) sebanyak 266 ekor berat $1.022,3 \mathrm{~kg}$ dengan panjang total (TL) minimum $32,5 \mathrm{~cm}$ dan maksimum $88,0 \mathrm{~cm}$, berat (W) minimum 0,4 $\mathrm{kg}$ dan maksimum $8,9 \mathrm{~kg}$.

c. Kakap merah (Lutjanus erythropterus) sebanyak 120 ekor berat $432,0 \mathrm{~kg}$ dengan panjang total (TL) minimum $36,0 \mathrm{~cm}$ dan maksimum $83,0 \mathrm{~cm}$, berat (W) minimum 0,5 $\mathrm{kg}$ dan maksimum $7,4 \mathrm{~kg}$.

d. Babi atau lencam (Lethrinus lencam) sebanyak 120 ekor berat $252,4 \mathrm{~kg}$ dengan panjang total (TL) minimum $36,0 \mathrm{~cm}$ dan maksimum 63,5 $\mathrm{cm}$, berat $(\mathrm{W})$ minimum $1,2 \mathrm{~kg}$ dan maksimum $4,0 \mathrm{~kg}$.

e. Kakap seto (Lutjanus sebae) sebanyak 84 ekor berat $253,8 \mathrm{~kg}$ dengan panjang total (TL) minimum $35,0 \mathrm{~cm}$ dan maksimum $85,0 \mathrm{~cm}$, berat (W) minimum $0,6 \mathrm{~kg}$ dan maksimum 6,6 $\mathrm{kg}$.

f. Kakap putih (Lutjanus vittus) sebanyak 58 ekor berat $130,7 \mathrm{~kg}$ dengan panjang total (TL) minimum $36,0 \mathrm{~cm}$ dan maksimum $63,5 \mathrm{~cm}$, berat (W) minimum 1,2 $\mathrm{kg}$ dan maksimum 5,1 $\mathrm{kg}$.

g. Kakap merah (Lutjanus timoriensis) sebanyak 60 ekor berat $162,0 \mathrm{~kg}$ dengan panjang total (TL) minimum 35,0 cm dan maksimum 69,5 $\mathrm{cm}$, berat $(\mathrm{W})$ minimum $0,7 \mathrm{~kg}$ dan maksimum $5,4 \mathrm{~kg}$.

\section{KESIMPULAN}

1. Banyaknya pukat harimau di perairan Arafura menyebabkan laju tangkap hook rate rata-rata pancing rawai dasar dari tahun ke tahun mengalami penurunan dan bila tidak ada pengendalian maka dikhawatirkan akan mengalami kepunahan dan penurunan stok terhadap ikan kakap.

2. Hasil tangkapan KM. Laut Tri yang digunakan dalam kegiatan observasi dari 61 kali setting dengan jumlah rata-rata mata pancing 1.786 buah berhasil tertangkap ikan sebanyak 2.850 ikan dengan berat $7.731,3 \mathrm{~kg}$. dengan demikian laju tangkap hook rate ratarata hanya 46,72 ekor $(2,61 \%)$ dengan berat $126,74 \mathrm{~kg}(7,09 \%)$, yang berarti jauh di bawah standar yaitu minimal $30 \%$.

3. Dominan hasil tangkapan adalah kakap merah (Lutjanus malabaricus) sebanyak 606 ekor $(21,26 \%)$ dengan berat $2.047,9 \mathrm{~kg}(26,49 \%)$.

4. Kapal belum dilengkapi dengan peralatan teknologi canggih sehingga belum mampu mendeteksi gerombolan ikan, dan alat tangkap pancing rawai dasar tersebut tidak efisien.

\section{UCAPAN TERIMA KASIH}

Penulis menghaturkan terima kasih sebesarbesarnya kepada Bapak Drs. Bambang Sumiono yang telah memberikan saran dan koreksinya, juga kepada pengetik naskah dan penerbit sehingga dapat terlaksananya tulisan ini. 